\title{
Urgensi Peta Dakwah
}

\author{
Rohmanur Aziz \\ UIN Sunan Gunung Djati Bandung \\ E-mail: ronaz@uinsgd.ac.id
}

\begin{abstract}
The existence of religious activity in society can not be separated from activities that are the rituals, routines are conducted in accordance religious agenda each and there are social activities that are more flexible with the time scheduled by the will of the people. The function of religious activities is to realize the servitude of man as a creature to his Lord by running various rules and religious guidance. The position of religion must be understood as the representation of the will of God revealed in scripture through the intermediary of the Prophets and Messengers as a messenger of God. The function of these religious activities which in turn drive the human civilization both worldly materialistic nature (world view) and the nature of eschatological things.
\end{abstract}

\section{Kata Kunci:}

Peta Dakwah, Pendekatan Dakwah, Masyarakat Dakwah

\section{A. Pendahuluan}

Ada fenomena yang dapat menjadi pelajaran di fakultas Dakwah \& Komunikasi yaitu dalam hal memperlakukan satu surat dalam al-Quran yaitu surat An-Nahl ayat 125. Bagi mahasiswa fakultas Dakwah \& Komunikasi, ayat ini seolah menjadi ayat wajib hafal walaupun kebanyakan kandas hanya sampai kalimat bi al-hikmah. Setiap mata kuliah yang berhubungan dengan konsep dan keilmuan dakwah, para dosen dan mahasiswa tidak pernah bosan untuk menyitir ayat ini. Begitupula mahasiswa dan dosen di fakultas Tarbiyah dan Keguruan, Keluasan ayat ini menjadi sempit dan terjadi pendangkalan terhadap maknanya. Layaknya fenomena ayam mengerami telur, bagi kebanyakan orang dianggap biasa dan tidak lebih dari sekedar proses regenerasi sang induk ayam. Tapi lain halnya bagi seorang bernama Thomas Alfa Edison, telur ayam yang ada dikandangnya, malah diambil 
alih untuk dierami. Layaknya induk ayam, Edison sabar mengerami telur-telur ayam hingga menetas dan ia pun menjadi ibu dan ayah dari anak-anak ayam. Sekilas, kisah ini menggambarkan "kegilaan" seorang Edison, namun jika dicermati ternyata fenomena itu menjadi dahsyat setelah hasil "tapabrata" Edison di kandang ayam menghasilkan lampu pijar hingga penemuan itu berkembang hingga sekarang.

Ini hanya analogi bahwa pemaknaan terhadap ayat-ayat quraniyah (tekstual) dan kauniyah (kontekstual) perlu dioptimalkan dan didukung oleh kearifan yang luhur sehingga bertemu pada kesejatian makna. Yang dimaksud dengan kesejatian makna adalah pada saat terjadi korelasi positif antara penjelasan tentang hakikat ayat yang diketahui dengan nilai guna bagi kemanfaatan peradaban manusia.

Penjelasan dari An-Nahl ayat 125 seyogianya lebih membumi dengan langkah-langkah rinci secara operasional. Perintah dakwah pada ayat tersebut difahami sebagai formalisasi kehendak Allah agar Nabi dan umatnya hidup dan menjalani kehidupan yang sesuai dengan kehendak-Nya. Adapun kehendak atau iradah Allah dalam dakwah adalah dengan hikmah, nasihat yang baik, dan dialektika yang santun dan ketiga-tiganya adalah pilihan jalan yang Allah ajarkan kepada Nabi dan umatnya sehingga ketiganya menjadi pilihan untuk mengembangkan ajaran Islam kepada seluruh umat manusia yang karakteristiknya memerlukan 3 pendekatan itu. Sebagaimana alat transportasi ada darat, laut dan udara, dakwah pun demikian. Hikmah adalah jalan darat sebagaimana dicontohkan oleh Lukman al-Hakim yang senantiasa sabar mendakwahi anak-anaknya secara langsung tatap muka (face to face) agar mereka senantiasa menyembah Allah dengan sungguh-sungguh. Mauidzah hasanah, layaknya dakwah jalur udara dapat dilakukan dengan nasihat-nasihat jarak jauh dengan media elektronik memanfaatkan gelombang elektromagnetik untuk mengajak manusia agar patuh pada Allah walaupun tidak melihat-Nya. Goals dari mauidzah hasanah adalah menjadikan mad'u sebagai manusia-manusia yang punya integritas moral tinggi. Sedangkan wa jaadil hum bi al-lati hiya ahsan adalah gambaran dialektika kesantunan layaknya angkatan laut yang harus menaklukan samudera untuk sebuah kemenangan dan mendapat tujuan yang diharapkan.

Sehingga tiga jalan yang Allah ajarkan dalam An-Nahl 125 berujung pada kesatuan tujuan yaitu keterpeliharaan tatanan sistem kehidupan sebagaimana terpeliharanya semesta raya yang dipelihara 
oleh Allah. Penampakan kesederhanaan An-Nahl 125 adalah representasi ke Maha Agungan dan ke-Maha Bijaksanaan Allah dalam penyampaian firman-firman-Nya. Namun, ketidakberdayaan dan kelemahan manusia membuat luasnya samudera ilmu Allah terhijab tidak menembus bumi dan tidak menjadi seperti jejak-jejak para nabi dalam menyampaikan pesan-pesan bernilai Maha Tinggi.

Pada mulanya, manusia lahir dalam keadaan suci kemudian tumbuh diiringi dengan kotoran dosa. Dakwah Islam menjadi upaya proses penyucian manusia agar kembali suci untuk menghadap Tuhan Yang Maha Suci dengan penuh kepantasan berupa kesucian diri.

\section{B. Pendekatan Dakwah}

Eksistensi kegiatan keagamaan di masyarakat tidak terlepas dari kegiatan yang sifatnya ritual, rutin dilaksankan sesuai agenda agama masing-masing dan ada kegiatan yang sifatnya sosial dengan waktu yang lebih leluasa diagendakan oleh kehendak masyarakat. Fungsi kegiatan keagamaan adalah untuk mewujudkan penghambaan manusia sebagai makhluk kepada Tuhannya dengan menjalankan berbagai aturan dan tuntunan agama. Posisi agama tentunya difahami sebagai representasi kehendak Tuhan yang diturunkan dalam kitab suci (secred books) melalui perantara para Nabi dan Rasul sebagai utusan Tuhan. Fungsi kegiatan keagamaan ini yang pada gilirannya menggerakkan peradaban manusia baik yang sifatnya duniawi materialistik (world view) maupun yang sifatnya ukhrawi eskatologis. Hal ini yang memicu Wilfred Cantwell Smith (2005: 22) menyampaikan usulan bahwa kitab suci adalah sebuah aktifitas manusia.

Smith telah menguatkan kerasulan Nabi Muhammad Saw yang dalam gambaran isterinya Siti 'Aisyah, akhlaq Nabi itu: "kaana khuluquhu al-Quran" (aktifitasnya adalah al-Quran). Ini yang kemudian Quraish Shihab (1996: 193) menyebut bahwa al-Quran al-Karim adalah suatu kitab dakwah yang mencakup sekian banyak permasalahan atau unsur dakwah, seperti da'i (pemberi dakwah), mad'u (penerima dakwah), pesan da'wah, metode dakwah dan cara-cara penyampaiannya.

Terdapat beberapa pendekatan operasional dakwah yang dilaksankan oleh Nabi Muhammad Saw, yaitu:

1. Pendekatan Personal (Fardliyah) 
Pendekatan dengan cara ini individual yaitu antara da'i dan mad'u langsung bertatap muka sehingga materi yang disampaikan langsung diterima dan biasanya reaksi yang ditimbulkan oleh mad'u akan langsung diketahui. Pendekatan dakwah seperti ini pernah dilakukan pada zaman Rasulullah ketika berdakwah secara rahasia. Meskipun demikian tidak menutup kemungkinan di era modern ini pendekatan personal tetap harus dilakukan karena mad'u terdiri dari berbagai karakteristik. Disinilah letak elastisitas pendekatan dakwah.

Pendekatan personal dilakukan oleh Nabi sejak turunnya wahyu pertama kepada orang-orang terdekatnya secara rahasia. Pendekatan model ini dilakukan agar tidak menimbulkan guncangan reaksioner dikalangan masyarakat Quraisy mengingat saat itu mereka masih berpegang teguh kepada kepercayaan animism warisan leluhur mereka. Dakwah secara personal ini berlangsung selama tiga tahun, dan diantara yang beriman pada saat itu adalah Khadijah binti Khuwalid, Ali bin Abi Thalib, Zaid bin Haritsah, Abu Bakar as-sidik, Ustman bin Affan, Zubair al-Arqam dan lain sebagainya (Sa'ad, 1980: 199).

Kegiatan dakwah melalui pendekatan personal nampaknya kurang populer dikalangan para da'i kontemporer. Hal ini terindikasi dari rapuhnya rasa senasib sepenanggungan antara para da'i dan orang-orang disekitar tempat domisilinya bahkan tidak sedikit da'i yang kurang mendapat dukungan dari keluarga dan tetangga dekatnya. Sementara ditempat yang jauh da'i tersebut dibutuhkan ilmu pengetahuannya serta dikenal luas sebagai orang yang selalu mengajak pada kebaikan.

Dilain pihak, para pendeta agama Kristen sangat mengandalkan dakwah mereka dengan pendekatan personal dengan ramah, santun dan memikat. Hal ini cukup membuat sebagian da'i di kalangan umat Islam cemburu tak menentu. Da'i di kalangan muslim pada gilirannya bersikap reaksioner dan emosional, enggan untuk meniru apa yang dicontohkan Nabi. Beberapa kasus yang terjadi pada akhir tahun 2014 memperlihatkan para misionaris Kristen membagi-bagikan cinderamata kepada masyarakat pada kegiatan car free day di Bandung dan Jakarta secara simpatik. Sontak kegiatan tersebut memunculkan reaksi emosional para khatib Jum'at yang melek 
informasi dengan mengecam kegiatan tersebut, walaupun ada antitesa dari para da'i muda yang membuat program simpatik tandingan berupa Menghafal Quran on the Road dan dakwah dengan pembagian jilbab gratis sekaligus saling memasangkannya yang diadakan oleh komunitas Dakwah Akhwat Mulia dan Generasi Kaffah di Jakarta.

2. Pendekatan Pendidikan

Pada masa Nabi, dakwah melalui pendidikan dilakukan beriringan dengan masuknya Islam kepada para kalangan sahabat. Kegiatan ini dilakukan dari rumah ke rumah, maka rumah sahabat al-Arqam ibn abi Arqam dijadikan sebagai tempat pertama penyampaian dakwah Islam secara berkelompok, selain itu tempat lain yang digunakan adalah asShuffah, Dar al-Qura dan Kuffah.

Begitu juga pada masa sekarang ini, kita dapat melihat pendekatan pendidikan teraplikasi dalam lembaga-lembaga pendidikan pesantren, yayasan yang bercorak Islam ataupun perguruan tinggi yang di dalamnya terdapat materi-materi keislaman (Suparta dan Hefni, 2003: 22-23).

Sebenarnya ketika wahyu pertama turun, maka pada saat itu Nabi mulai berfungsi sebagai seorang pendidik dan pembimbing masyarakat (Sosial educator), melalui perombakan dan revolusi mental masyarakat Arab dari kebiasaan menyembah berhala yang merendahkan derajat kemanusiaan dan tidak menggunakan akal pikiran yang sehat, tidak memiliki prikemanusiaan dan menghinakan kaum wanita dan sebagainya, menuju sikap mental yang mengangkat derajat kemanusiaan yang penuh percaya diri dan hanya menyembah dan memohon perlindungan kepada Alloh SWT.

Adapun sistem pembinaan dan pendidikan yang dikembangkan oleh Nabi adalah sistem kaderisasi dengan membina beberapa orang sahabat. Kemudian para sahabat mengembangkannya lagi ke seluruh dunia. Dimulai dari khulafa al-Rasyidun, kemudian generasi berikutnya. Dimulai dari pembinaan dan kaderisasi di Makkah yang agak terbatas kemudian di Madinah dengan membentuk komunitas muslim ditengah-tengah masyarakat Madinah yang cukup heterogen (Muhyiddin dan Safei, 2002: 106-107). Pada pinggir masjid 
Nabawi, Nabi membuatkan lantai yang agak tinggi untuk anakanak angkat yang dikemudian hari disebuat dengan ahlussuffah. Salaha satu murid Nabi yang tercatat sukses adalah Anas bin Malik.

Dalam sejarah Islam, masjid merupakan tempat strategis untuk berbagai kegiatan masyarakat muslim baik pada masa Nabi hingga masa sekarang. Fakta menunjukkan bahwa universitas Al-Azhar Mesir adalah perguruan tinggi pertama di dunia yang didirikan di masjid pada masa dinasti Bani Fathimiyah. Di Indonesia, dakwah melalui pendidikan Islam dikemukakan oleh Azyumardi Azra dan Muarif Ambari berasal dari surau atau masjid yang difungsikan bukan hanya kegiatan ritual ibadah tetapi juga dipakai kegiatan belajar mengajar terutama dalam kajian Islam.

Dalam perkembangannya, pendekatan pendidikan semakin kokoh melalui proses pelembagaan yang dikelola oleh negara dan pihak swasta mulai dari pesantren tradisional, madrasah, sekolah Islam terpadu, pesantren unggulan, hingga program aksi pendidikan menjangkau pelosok daerah seperti pada progam Indonesia Mengajar yang di prakarsai oleh tokoh cendekiawan muslim Anies Baswedan merupakan salahsatu manifestasi dari formulasi dakwah dengan pendekatan misi. Namun pada program tersebut akan tampak misi yang lebih universal yaitu mencerdaskan kehidupan bangsa.

\section{Pendekatan Penawaran}

Salah satu falsafah pendekatan penawaran yang dilakukan Nabi adalah ajakan untuk beriman kepada Alloh tanpa menyekutukan-Nya dengan yang lain. Cara ini dilakukan Nabi dengan memakai metode yang tepat tanpa paksaan sehingga mad'u ketika meresponnya tidak dalam keadaan tertekan bahkan ia melakukannya dengan niat yang timbul dari hati yang paling dalam. Cara ini pun harus dilakukan oleh da'i dalam mengajak mad'unya. Fakta sejarah menunjukkan bahwa pendekatan penawaran yang berkolaborasi dengan dengan pendekatan lain seperti personal dan korespondensi, tampak bahwa surat-surat Nabi yang disampaikan kepada raja-raja pada masa itu termasuk Heraklius (raja kerajaan Romawi) adalah 
pendekatan penawaran sebagai optimalisasi ikhtiar dakwah melalui jalur diplomasi.

Dalam konteks ini, tawaran konsep masyarakat madani melalui dakwah multikultural lebih dibutuhkan untuk membangun kesepahaman terlebih dahulu tentang keniscayaan dari realitas keragaman agama dan budaya. Setelah itu, diperlukan agenda selanjutnya berupa penjelasan pandanganpandangan Islam tentang berbagai problematika kehidupan. Langkah ini diharapkan dapat mentransformasi hidayah untuk seluruh manusia dengan mengedepankan paradigma Islam yang rahmatan lil 'alamiin.

\section{Pendekatan Misi}

Maksud dari pendekatan misi adalah pengiriman tenaga para da'i ke daerah-daerah di luar tempat domisili.Kita bisa mencermati pada masa sekarang ini, ada banyak organisasi yang bergerak dibidang dakwah mengirimkan da'i mereka untuk disebarluaskan ke daerah-daerah yang minim para da'inya, dan disamping itu daerah yang menjadi tujuan adalah biasanya kurang memahami ajaran Islam yang prinsipil. Model yang lain Jamaah Tabligh Indonesia (JTI) lebih opensif menggunakan pendekatan misi dengan melakukan program khuruj, yaitu kegiatan keluar dari kampung halaman secara berkelompok menuju masjid-masjid di seluruh pelosok dunia sebagai tempat untuk silaturrahim dan menyusun strategi dakwah. Kata khuruj itu sendiri berasal dari kata kharaja yang berarti keluar. Kata ini diambil dari kata ukhrijat yang terdapat dalam Q.S Ali Imran [3] ayat 110.

Syukriadi Sambas menyebut bahwa dalam kegiatan akan akademik di Perguruan Tinggi terdapat program Kuliah Kerja Nyata (KKN) atau Kuliah Kerja Mahasiswa (KKM). Program ini menjadi salahsatu wujud dari pendekatan misi pengabdian masyarakat melalui kegiatan keluar dari kampus dan berbaur melaksankan pengabdian langsung di masyarakat dengan batas waktu dan tempat yang ditentukan oleh Perguruan Tinggi.

Pendekatan-pendekatan diatas adalah sebagian kecil dari seluruh pendekatan yang ada dan semua bisa dijadikan acuan oleh para da'i dalam melakukan kegiatan dakwahnya. 
Pendekatan misi ini pernah dilakukan oleh Nabi di Makkah, tapi belum berhasil, kemudian dikembangkan di Madinah dengan hasil yang maksimal. Pendekatan serupa pula dilakukan secara besar-besaran pada zaman sahabat khususnya Umar ibn Khattab.

\section{Pendekatan Korespondensi}

Selain pendekatan-pendekatan di atas, dalam menyebarkan agama Islam Nabi juga melakukan dakwah dengan pendekatan korespondensi. Pendekatan korespondensi ini dilakukan oleh Nabi adalah dakwah dengan melalui surat. Setelah perdamaian Hudaibiyah, keadaan menjadi tenang, dan dakwah Islam mendapatkan ruang gerak untuk maju. Rasulullah SAW menulis surat kepada para raja dunia dan pemimpin Arab, mengajak mereka untuk masuk Islam, menuju jalan Tuhannya dengan cara bijaksana dan nasihat yang baik. Beliau sangat memperhatikan hal ini dan memilih orang yang diutus yang mengetahui bahasa dan negaranya.

Dikatakan kepada beliau bahwa mereka tidak menerima surat kecuali dengan suatu tanda (stempel), lalu Rasulullah SAW membuat stempel dari perak bertuliskan "Muhammad Rasulullah". Pengiriman surat-surat ini menunjukan bahwa Islam bukan agama orang Arab saja atau agama jazirah Arab saja. Ia merupakan agama manusia dan agama kemanusiaan, yang merupakan peringatan bagi para penguasa bagi yang kekuasaannya diluar jazirah (Arab) dan sekitarnya, dan penguasa yang ada disegala penjuru, bahwa mereka terancam untuk musnah jika tidak menerima dakwah Islam atau mengizinkan paling tidak untuk menjadikan rakyatnya mengetahui dakwah Islam ini, mendengarnya dan menentukan nasibnya.

Diantara para raja tersebut adalah raja Romawi (Heraclius), raja Persia (Kisra Abrawaiz), raja Habsy (Najasyi), dan raja Mesir (Muqauqis) (An-Nadwi, 2001: 341-343).

6. Pendekatan Diskusi

Pendekatan diskusi pada era sekarang sering dilakukan lewat berbagai diskusi keagamaan, da'i berperan sebagai 
narasumber, sedangkan mad'u berperan sebagai audience. Tujuan dari diskusi ini adalah membahas dan menemukan pemecahan semua problematika yang ada kaitannya dengan dakwah sehingga apa yang menjadi permasalahan dapat ditemukan jalan keluarnya.

Dalam keterangan lain dikatakan bahwa keberhasilan Nabi Muhammad dalam mengemban misi profetiknya, disebabkan oleh beberapa faktor. Namun diantaranya sekian banyak faktor, yang paling dominan menyebabkan keberhasilan Nabi Muhammad dalam berperan sebagai Nabi, adalah faktor kepiawaian Nabi dalam menerapkan strategi atau pendekatan dakwahnya. Adapun langkah dakwah yang ditempuh oleh Nabi Muhammad adalah sebagai berikut:

a. Dakwah nafsiah, yaitu dakwah yang bersifat intra personal (intra personal communication), term ini diistibnbath dari QS. 66:6,

"Hai orang-orang yang beriman, peliharalah dirimu dan keluargamu dari api neraka....."

Dakwah pada level ini telah dilakukan oleh Nabi jauh sebelum beliau dibi'tsah menjadi Nabi dan Rasul. Sehingga masyarakat Arab menggelari Nabi dengan sebutan al-Amin.

b. Dakwah fardiyah, yaitu dakwah yang bersifat interpersonal (interpersonal communication), term ini diinstinbathkan dari QS. 34:46

"Katakanlah, sesungguhnya aku hendak memperingatkan kepadamu suatu hal saja, yaitu supaya kamu menghadap Alloh (dengan ikhlas) berdua-dua atau sendiri-sendiri, kemudian kamu pikirkan (tentang Muhammad) tidak ada penyakit gila sedikitpun pada kawanmu itu. Dia tidak lain hanyalah pemberi peringatan bagi kamu sebelum menghadapi azab yang keras."

Dakwah pada level ini, dilakukan terhadap orang-orang terdekat dengan baik, diantaranya Ali ibn Abu Thalib, Khadijah, Abu Bakar, Zaid, dan Ummu Aiman.

c. Dakwah fi ah, yaitu dakwah yang dilakukan terhadap kelompok-kelompok kecil (small group communication), term ini diinstinbathkan dari QS. 2: 249 
"....Berapa banyak golongan yang sedikit dapat mengalahkan golongan yang banyak dengan izin Alloh. Dan Alloh beserta orang-orang yang sabar."

Dakwah pada level ini pertama kali dilakukan oleh Nabi pada keluarga bani Abdul Muthalib, berdasarkan perintah Alloh dalam QS. 26: 214

"Dan berilah peringatan kepada kerabat-kerabatmu yang terdekat"

d. Dakwah Hizbiyah, yaitu dakwah lewat pendekatan organisasi (organizational communication), term ini diistinbath dari QS. 5:56

"Dan barang siapa mengambil Alloh dan Rasul-Nya, dan orang-orang yang beriman menjadi penolongnya, maka sesungguhnya pengikut (agama Alloh), itulah yang pasti menang."

Dakwah pada level yang keempat ini dilakukan Nabi kepada organisasi-organisasi terkemuka dan memiliki pengaruh pada saat itu seperti pada Nadi Quraisy (organisasi penya'ir Quraisy) dan Darun Nadwah (organisasi yang mengelola kegiatan diseputar ka'bah).

e. Dakwah Ummah, yaitu dakwah pada khalayak (masa) secara menyeluruh (mass communication), term ini diistinbath dari QS. 2:128,143.

"Ya Tuhan kami, jadikanlah kami orang yang tunduk patuh kepada Engkau dan (jadikanlah) diantara anak cucu kami umatyang tunduk patuh kepada Engkau...."

"Dan demikian (pula) kami telah menjadikan kamu (umat Islam) umat yang adil dan pilihan..."

Pendekatan dakwah ini dilakukan oleh Nabi setelah mendapat advokasi masa yang banyak, dan perintah dari Alloh dalam QS. 15:94

"Maka sampaikanlah olehmu secara terang-terangan segala apa yang diperintahkan (kepadamu), dan berpalinglah dari orang-orang musyrik."

f. Dakwah Syu'ubiyah - Qaba'iliyah, yaitu gerakan dakwah yang bersifat lintas bangsa dan lintas budaya, term ini diistinbath dari QS. 49:13. 
"Hai manusia sesungguhnya Kami menciptakan kamu dari seorang laki-laki dan seorang perempuan dan menjadikan kamu berbangsa-bangsa bersuku-suku supaya kamu saling kenal mengenal. Sesungguhnya orang yang paling mulia diantara kamu disisi Alloh adalah orang yang bertaqwa."

Pada level keenam ini, aksi dakwah dilakukan oleh Nabi setelah beliau memiliki kekuatan ganda, yaitu sebagai penyampai misi profetik dan pemimpin politik. Resistensi aksi dakwah ini, lebih banyak dilakukan oleh Nabi ketika beliau berada di Madinah (Abdullah, 2002: 67). Namun dinamika masyarakat madinah kemudian memberi inspirasi pada gagasan civil society madzhab masyarakat madani yang dibentuk oleh gerakan dakwah Muhammad Saw. Gerakan ini memiliki paradigma yang paripurna, yaitu paradigma holistik integralistik, bahwa dakwah tidak dipartisi sebagai locus agama yang hanya berbicara tentang persoalan privat yang berkutat pada hubungan seseorang dengan Tuhannya saja, tetapi dakwah sebagai aktifitas luas yang menjangkau locus sosial bahkan secara iqtibasy akan sangat beririsan dengan berbagai aspek kehidupan dan berbagai disiplin ilmu hingga ke sains dan teknologi.

\section{Karakteristik Masyarakat Dakwah}

Konsep masyarakat dalam terminology Arab berasal dari kata syaraka, bermakna sekumpulan manusia yang saling berinteraksi dan partisipatif. Selo Sumarjan menyebut bahwa masyarakat adalah sekumpulan orang yang hidup bersama dan menghasilkan kebudayaan.Sedangkan menurut Koentjaraningrat, masyarakat adalah kesatuan hidup manusia yang berinteraksi menurut satu system adat istiadat tertentu yang bersifat kontiu dan terikat oleh suatu rasa identitas yang sama.Dengan demikian, kajian tentang masyarakat adalah kajian tentang proses hubungan manusia sebagai makhluk sosial.

Karakteristik masyarakat dapat ditandai dari ciri-ciri yang dimiliki oleh masyarakat itu sendiri yaitu:

1. Interaksi diantara sesama anggota;

2. Menempati wilayah dengan batasan-batasan tertentu;

3. Saling bergantung satu dengan lainnya;

4. Memiliki adat istiadat tertentu/ budaya;

5. Memiliki identitas. 
Masyarakat dakwah dapat difahami sebagai subjek dan objek dakwah. Sebagai subjek, masyarakat dakwah adalah sekumpulan orang yang sedang melakukan proses penyadaran melalui penyampaian pesan-pesan teologis (al-Quran dan al-Sunnah) agar membumi pada tataran sosiologis dan mewujud pada perubahan sosial kearah yang lebih baik sesuai harapan masyarakat itu sendiri. Sedangkan sebagai objek, masyarakat dakwah adalah kumpulan manusia yang sedang diteliti dan diprogram agar terjadi perubahan sosial kearah yang lebih baik sesuai harapan masyarakat itu sendiri.

Terlepas dari posisinya sebagai subjek atau objek dakwah, masyarakat dakwah dapat diurai dalam beberapa kategori karakteristik,menurut faktor-faktor yang mempengaruhinya yaitu sebagai berikut:

1. Letak geografis

Lokasi tempat domisili suatu masyarakat memunculkan deferensiasi yang mencolok antara masyarakat kota, desa, pesisir, gurun, tropis dan non tropis. Masing-masing wilayah memiliki karakteristik yang berbeda dalam menerima pesan dakwah dan menyampaikan pesan dakwah. Dalam konteks ini tidak lagi berbicara suku bangsa seperti Batak, Sunda, Jawa, Melayu dan sebagainya, tetapi lebih pada kondisi objektif pengaruh kondisi alam tempat domisili suatu masyarakat. Masyarakat pesisir dan gurun tampaknya lebih mudah menerima pesan-pesan dakwah tentang nilai-nilai keyakinan dan mistik ketimbang masyarakat pegunungan yang lebih mudah menerima pesan tentang tata aturan beragama seperti fiqih dan akhlak. Pada konteks ini perlu dikembangkan berbagai penelitian dakwah berdasar pada karakteristik masyarakat di berbagai daerah yang letak geografisnya berbeda-beda.

2. Tingkat pendidikan

Berdasarkan tingkat pendidikannya, karakteristik masyarakat dakwah pada masyarakat pelajar/ santri dengan masyarakat awam terdapat perbedaan yang signifikan. Demikianpun pada masyarakat pendidikan setiap level memiliki perbedaan karakteristik sesuai dengan psikologi perkembangan mulai tingkat Pendidikan Anak Usia Dini (PAUD), Sekolah Dasar (SD), Sekolah Lajutan Tingkat 
Pertama (SLTP), Sekolah Menengah Tingkat Atas (SLTA) dan perguruan tinggi.

3. Faham dan doktrin ideology organisasi;

Latar belakang madzhab dan fanatisme organisasi. Pada perbandingan dakwah antara organisasi masyarakat, Nampak berbeda antara masyarakat Muhammadiyah, Mathla'ul Anwar, Persis, NU, PUI, FPI, HTI, Salafi, Jema'ah Tabligh Indonesia dan sebagainya.

4. Status sosial dan ekonomi

Cliford Geertz menyebut tiga kategori muslim Jawa, yaitu priyayi, santri dan abangan. Hasil penelitian Geertz menegaskan bahwa secara sosiologis, di masyarakat ada stratifikasi sosial secara ekonomi dan secara sosial. Pendekatan dakwah kepada birokrat dan rakyat akan berbeda walaupun perlakuan harus tetap sama (egaliter).Stratifikasi sosial terbagai tiga; pertama, lower class yaitu masyarakat yang secara sosial ekonomi berada pada posisi rakyat yang belum mendapatkan penghasilan tetap atau kalaupun memiliki penghasilan hanya sanggup untuk memenuhi kebutuhan pangan/ biologis saja. Hidupnya dipertahankan dengan pendekatan pragmatis dan memiliki sistem keyakinan yang masih bergantung pada ketokohan seseorang. Masyarakat pada level ini ada pada masyarakat buruh baik tani, nelayan, maupun industri. Kedua, middle class, atau masyarakat menenengah yaitu masyarakat yang sudah terpenuhi kebutuhan biologisnya dan mulai dapat memenuhi kebutuhan sandang dan papan. Masyarakat pada level ini biasanya ada pada masyarakat professional yang pendapatannya bergantung pada bayaran/ gaji dari keahlian pada bidang tertentu seperti Pegawai Negeri Sipil, TNI/Polri, dokter dan sebagainya. Ketiga high class, yaitu lapisan masyarakat yang telah meraih berbagai kebutuhannya secara mudah akibat dari kepemilikan harta dan status sosialnya. Mereka mudah untuk memenuhi berbagai kebutuhannya baik kebutuhan sandang, pangan, papan, aktualisasi diri/ psikologis, bahkan kebutuhan spiritualitas seperti menunaikan ibadah umrah 
dan haji. Masyarakat high class ini hanya terdiri dari para pejabat dan pengusaha sukses saja.

5. Budaya

Sebagai produk dari kreatifitas manusia, realitas budaya masyarakat menjadi ciri khas dominan dalam memperlihatkan eksistensinya. Budaya masyarakat adat seperti Minang, Baduy, kampung Naga, adat Cireundeu, adat Jawa, Dayak, Papua dan sebagainya memerlukan perangkat metodologi dakwah yang mumpuni. Menyikapi pluralitas budaya di Indonesia ini, Cak Nur dipandang telah melakukan gerakan dakwah melalui serangkaian gagasan Islam dalam ke-Indonesiaan dan Gus Dur dengan gagasan pribumisasi Islam.

Dalam melaksankan aktifitas dakwah seyogyanya para da'i mempelajari dan mempersiapkan kerangka metodologis dalam menyikapi keragaman dan kompleksitas proses sosial yang terjadi di masyarakat. Menurut Gillin dan Gillin dalam Soekanto (2002: 71-104), menjelaskan bahwa ada dua golongan proses sosial sebagai akibat dari interaksi sosial, yaitu proses sosial asosiatif dan proses sosial disasosiatif. Proses asosiatif adalah proses yang terjadi saling pengertian dan kerjasama timbal bailk antara orang per orang atau kelompok satu dengan lainnya, dimana proses ini menghasilkan pencapaian tujuan-tujuan bersama, yaitu kerjasama (corporation) dan acomodation. Beberapa bentuk kerjasama yaitu: gotong royong, bargaining, co-optation, coalition, dan joint-venture. Adapun accommodation adalah proses sosial dengan dua makana, pertama, adalah proses sosial yang menunjukkan pada suatu keadaan yang seimbang (equilibrium) dalam interaksi sosial antara individu dan antar kelompok di dalam masyarakat, terutama yang ada hubungannya dengan norma-norma dan nilai-nilai sosial yang berlaku dalam masyarakat tersebut. Kedua adalah menuju pada suatu proses yang sedang berlangsung, dimana accommodation menampakkan suatu proses untuk meredakan suatu pertentangan yang terjadi di masyarakat, baik pertentangan yang terjadi diantara individu, kelompok dan masyarakat, maupun dengan norma dan nilai yang ada di masyarakat itu. Bentuk accommodation ada tujuh coersion, compromise, mediation, conciliation, tolerantion, stalemate, dan adjudication. 
Sedangkan disasosiatif merupakan proses perlawanan yang dilakukan oleh individu-individu dan kelompok dalam proses sosial diantara mereka pada suatu masyarakat. Bentuk proses disasosiatif adalah persaingan, kompetisi, dan konflik (Bungin, 2006: 58-63).

Kedua proses sosial tersebut sejatinya hadir ditengah masyarakat dan telah terjadi sejak masyarakat itu sendiri terbentuk di masa permulaan (muqadimah). Dalam sejarah umat Islam, masyarakat madinah seyogyanya menjadi model civil society yang mengajar proses sosial dari ragam karakteristik masyarakat dakwah.

Masyarakat Madani adalah masyarakat yang berperadaban tinggi sarat dengan keteraturan hidup dalam berbagai aspek kehidupan. Konsep Masyarakat Madani berasal dari perbincangan konsep civil society yang secara historis terdapat di eropa dengan pengertian masyarkat sipil yang diciptakan sebagai tatanan masyarakat yang egaliter, demokratis, toleran dan inklusiv (Gellner, 2000). Namun keberadaan masyarakat sipil diyakini sebgai hasil cipta akal budi manusia eropa yang maju dan mendambakan peradaban yang menjunjung tinggi hak-hak dan nilai-nailai kemanusiaan. Dengan demikian civil society madzhab eropa ini bersifat antroposentris. Sedangkan konsep yang lain disampaikan oleh Anwar Ibrahim civil society sebagai tatanan masyarakat madani yang nilai-nilai nya diambil dari tatanan masyarakat madinah pada masa Nabi Muhammad saw hijrah dari Hijaz (Mekkah) ke Yatsrib dan kemudian menamakannya Madinah al-Munawaroh. Madinah berasal dari kata madaniyun artinya kota dan al-munawwaroh berarti bertabur cahaya.

Masyarakat madani atau civil society secara umum bisa diartikan sebagai suatu masyarakat atau institusi sosial yang memiliki ciri-ciri antara lain : kemandirian, toleransi, keswadayaan, kerelaan menolong satu sama lain, dan menjunjung tinggi norma dan etika yang disepakati secara bersama-sama (Syamsuddin, 1999: 12). Secara lugas konsep masyarakat madani menggambarkan kesadaran akan keteraturan system kehidupan dalam suatu tatanan masyarakat dengan dilandasi oleh nilai-nilai luhur kemanusiaan (N2LK).

Masyarakat madani atau masyarakat sipil (civil society) dalam wacana baku ilmu sosial pada dasarnya dipahami sebagai antitesa dari "masyarakat politik" atau negara. Pemikiran itu dapat dilacak dari pendapatnya Hobbes, Locke, Montesquieu, Hegel, Marx, Gramsci dan lain-lain. Pemikiran mengenai masyarakat sipil tumbuh dan 
berkembang sebagai bentuk koreksi radikal kepada eksistensi negara karena peranannya yang cenderung menjadi alat kapitalisme. Substansi pembahasannya terletak pada penggugatan hegemoni negara dalam melanggengkan kekuatan kelompok kapitalis dengan memarjinalkan peran masyarakat pada umumnya. Oleh sebab itu dibutuhkan sebuah kekuatan non-pemerintah yang mampu mengimbangi dan mencegah kekuatan negara untuk mengurangi tekanan-tekanan yang tidak adil kepada rakyatnya. Akan tetapi di sisi lain, mendukung peran pemerintah dalam menjadi juru damai dan penjaga keamanan dari kemungkinan konflik-konflik antar kepentingan dalam masyarakat.

Dengan kata lain perlu adanya reposisi struktural dan kultural antar komponen dalam masyarakat, sederhananya, "serahkan urusan rakyat pada rakyat, dan posisikan pemerintah sebagai pejaga malam".

Tujuan dari masyarakat madani adalah terwujudnya kesejahteraan, keadilan dan kemajuan dalam berbagai aspek kehidupan. Masyarakat madani bukan hanya tujuan tetapi perangkat cara yang mendorong suatu peradaban yang memanusiakan manusia.

Masyarakat madani jika dipahami secara sepintas merupakan format kehidupan sosial yang mengedepankan semangat demokrasi dan menjunjung tinggi nilai-nilai hak asasi manusia. Dalam masyarakat madani, warga negara bekerjasama membangun ikatan sosial, jaringan produktif dan solidaritas kemanusiaan yang bersifat non-govermental untuk mencapai kebaikan bersama. Karena itu, tekanan sentral masyarakat madani adalah terletak pada independensinya terhadap negara. Masyarakat madani berkeinginan membangun hubungan yang konsultatif bukan konfrontatif antara warga negara dan negara. Masyarakat madani juga tidak hanya bersikap dan berperilaku sebagai citizen yang memiliki hak dan kewajiban, melainkan juga harus menghormati equal right, memperlakukan semua warga negara sebagai pemegang hak kebebasan yang sama.

Ekspektasi terwujudnya masyarakat madani di Indonesia, dipandang relevan dengan kehendak Allah dalam Q.S.3:110 yaitu mewujudkan khoir al-ummah (civil society) melalui proses gerakan dakwah yang berkarakter bijak dalam bertindak dan bajik dalam bertutur kata. Ayat ini yang oleh Kuntowijoyo dijadikan kerangka dakwah atau yang lebih dikenal dengan sosiologi profetik. 


\section{Penutup}

Seyogyanya seluruh umat Islam mendapat pencerahan tentang dakwah sebagai kebutuhan sosial dalam membangun tatanan sistem sosial yang dapat memadukan antara ranah yang sifatnya sosiologis dan teologis. Secara teologis, dakwah adalah kewajiban, namun secara sosiologis dakwah adalah kebutuhan. Oleh karena kebutuhan itu, maka diperlukan informasi tentang berbagai karakteristik masyarakat sebagai da'i dan mad'u.Seiring dengan itu diperlukan perangkat metodologi yang dapat mensukseskan dakwah mulai dari level diri sendiri (nafsiyah) hingga dakwah multikultural bahkan global (da'wah ummah) sehingga dapat membentangkan belantara peta dakwah yang selama ini kurang mendapat perhatian serius para ulama. Peta dakwah akan menjadi penunjuk jalan bagi seluruh umat Islam yang terpanggil hati dan jiwa nya untuk berdakwah di jalan Allah, sehingga dapat mengetahui karakteristik masyarakat dakwah di setiap tempat yang berbeda butuh pendekatan dan metode yang berbeda pula.[]

\section{DAFTAR PUSTAKA}

Abdullah, Aang Ridwan, 2002. Menapaki Sunnah Menemukan Arah, Bandung: Fak Dakwah Institut Agama Islam Negeri Sunan Gunung Djati Bandung.

Abul Hasan 'Ali al-Hasani an-Nadwi, 2001. Sirah Nabawiyah, Yogyakarta: Mardhiyah Press

Bungin, Burhan, 2006. Sosiologi Komunikasi, Jakarta: Kencana, 2006.

Ibnu Sa'ad, 1980. Al-Thobaqat al-Kubra, Beirut: Dar el_Fikr

Muhyiddin, Asep dan Syafe'i, Ahmad Agus, 2002. Metode Pengembangan Dakwah, Bandung: Pustaka Setia.

Quraish Shihab, 1994. Membumikan Al-Quran, Bandung: Mizan

Suparta, Munzier dan Hefni, Harjani, 2003. Metode Dakwah, Jakarta: Kencana.

Syamsuddin, Din, 1999. Etika Agama dalam membangun Masyarakat Madani, Jakarta : Gramedia.

Wilfred Cantwell Smith, 2005. Kitab Suci Agama-Agama, Bandung; Mizan Media Utama. 